17 DeMonaco J, McGovern B. Transient asystole associated with amphotericin B infusion. Drug Intell Clin Pharm 1983;17:547-9.

18 Craven P, Gremillion D. Risk factors of ventricular fibrillation during rapid amphotericin B infusion. Antimicrob Agents Chemother 1985;27:868-71.

19 Braitburg J, Powderly W, Kobayashi G, Medoff G. Amphotericin B: delivery systems. Antmicrob Agents Chemother 1990;34:381-4.

20) Kirsh R, Goldstein R, Tarloff J, Parris D, Hook J, Hanna N, et al. An emulsion formulation of amphotericin $\mathrm{B}$ improves therapeutic index when treating systemic murine candidiasis. F Infect Dis 1988;158:1065-70

21 Barreuther A, Dodge R, Blondeaux A. Administration of amphotericin B Drug Intell Clin Pharm 1977;11:368-9.

22 Cleary J, Weisdorf D, Fletcher C. Effect of infusion rate on amphotericin B-associated febrile reactions. Drug Intell Clin Pharm 1988;22:769-72.

23 Emminger E, Lang $\mathrm{H}$, Emminger-Schmidmeier W, Peters C, Gadner $\mathrm{H}$ Amphotericin B serum levels in pediatric bone marrow transplant recipients. Bone Marrow Transplant 1991:7.95-9.

24 Olfield E, Garst P, Hostetter C, White M, Samuelsson D. Randomised, double-blind trial of 1 - versus 4-hour amphotericin B infusion durations. double-blind trial of 1 - versus 4-hour amphor

25 Colletre N, Van Der Auwera P, Pascual Lopez A, Heymans C, Meunier F. Tissue concentrations and bioactivity of amphotericin $\mathrm{B}$ in cancer patients Tissue concentrations and bioactivity of amphotericin B in cancer patients
treated with amphotericin B-deoxycholate. Antimicrob Agents Chemother 1989;33:362-8.

26 Fields B, Bates J, Abernathy R. Effect of rapid intravenous infusion on serum concentrations of amphotericin B. Applied Microbiology 1971;22:615-7.

27 Casagrande J, Pike M, Smith P. An improved approximate formula for calculating sample sizes for comparing two binomial distributions. Biometrics 1978;34:483-6.

28 Tarala R, Smith J. Cryptococcosis treated by rapid infusion of amphotericin B. BMF 1980;281:28.

29 Kan V, Bennett J, Amantea M, Smolskis MC, McMlanus E, Grasela DM, et al. Comparative safety, tolerance, and pharmacokinetics of amphotericin $B$ lipid complex and amphotericin B deoxycholate in healthy male volunteers. I Infect Dis 1991; 164:418-21.

30 hia J, McManus E. In vitro tumor necrosis factor induction assay for analysis this 7 of febrile toxicity associated with amphotericin B preparations. Antimicrob Agents Chemother 1990:34:906-8.

31 Gigliotti $F$, Shenep J, Lott L, Thornton D. Induction of prostaglandin synthesis as the mechanism responsible for chills and fever produced by infusion of amphotericin B. I Infect Dis 1987;156:784-9.

32 Bolard $\mathrm{J}$. How do the polyene macrolide antibiotics affect the cellular membrane properties? Biochem Biophys Acta 1986;864:257-304

33 Brajtburg J, Powderly W, Kobayashi G, Medoff G. Amphotericin B: current understanding of mechanisms of action. Antimicrob Agents Chemother 1990;34:183-8

34 Janoff A, Boni L, Popescu M, Minche SR, Cullis PR, Madden TD, et al. Unusual lipid structures selectively reduce the toxicity of amphotericin B. Proc Natl Acad Sci USA 1988;85:6122-6.

35 Joly V, Bolard J, Saint-Julien L, Carbon C, Yeni P. Influence of phospholipid/ amphotericin $B$ ratio and phospholipid type on in vitro renal cell toxicities and fungicidal activities of lipid-associated amphotericin B formulations. Antimicrob Agents Chemother 1992;36:262-6.

36 Jarnum S, Ladefoged $\mathrm{K}$. Long term parenteral nutrition I: clinical experience in 70 patients from 1967 to 1980 . Scand f Gastroenterol 1981;16:903-11.

37 Messing B, Latrive J, Bitoun A, Gallian A, Bernier J. La steatose hepatique au cours de la nutrition parenterale totale depend-elle de l'apport calorique lipidique? Gastroenterol Clin Biol 1979;3:719-24.

38 Atkinson A Bennett J. Amphotericin B pharmacokinetics in humans. Antimicrob Agents Chemother 1978;13:271-6.
Atinson A, Bennett J. Amphotericin B

39 Christiansen K, Bernard E, Gold J, Armstrong D. Distribution and activity of amphotericin B in humans. F Infect Dis 1985;152:1037-43.

40 Brajtburg J, Elberg S, Kobayashi G, Medoff G. Inhibition of amphotericin B (Fungizone) toxicity to cells by egg lecithin-glycocholic acid micelles. Antimicrob Agents Chemother 1990;34:2415-6.

41 Chavanet P, Charlier N, Brenet A, Goux A, Muggeo E, Caillot D, et al. Emulsion of amphotericin B in Intralipid 20\%: in vitro and in vivo efficacy. Path Biol 1992;40:507-12.

(Accepted 20 August 1992)
Directorate of Medicine, $\mathrm{St}$ James's University Hospital, Leeds)LS9 7TF Helen F Goode, senior clinical (research) scientist Barry E Walker, consultant physician

Department of Medicine for the Elderly, Leeds General Infirmary, Leeds LS1 3EX

Eileen Burns, consultant physician

Correspondence to: Dr Goode.

BM于 1992;305:925-7

\title{
Vitamin $\mathbf{C}$ depletion and pressure sores in elderly patients with femoral neck fracture/
}

\author{
Helen F Goode, Eileen Burns, Barry E Walker
}

\section{Abstract}

Objective-To evaluate the contribution of specific nutritional deficiencies (as indicated by zinc; vitamin $\mathbf{A}, \mathbf{C}$, and $\mathbf{E}$; albumin; and haemoglobin concentrations) to the risk of pressure sores.

Design-Observational cohort study.

Setting-St James's University Hospital, Leeds.

Subjects - 21 elderly patients presenting consecutively to the orthopaedic unit with femoral neck fracture.

Main outcome measure-Full thickness epidermal break over a pressure bearing surface.

Results -10 patients $(48 \%)$ developed a pressure sore during their hospital stay. Indices of zinc status and concentrations of albumin, haemoglobin, and vitamins $A$ and $\mathbf{E}$ were similar in patients who developed a pressure sore and those who did not. Mean leucocyte vitamin $\mathbf{C}$ concentration, however, was $6.3(S D 2.2) \mu \mathrm{g} / 10^{8}$ cells in patients who developed a pressure sore as compared with 12.8 (4.6) $\mu \mathrm{g} / 10^{8}$ cells in patients who did not.

Conclusions-Low concentrations of leucocyte vitamin $\mathbf{C}$ appear to be associated with subsequent development of pressure sores in elderly patients with femoral neck fractures.

\section{Introduction}

Up to $10 \%$ of all hospital patients and $30 \%$ of all elderly patients suffer from pressure sores. ${ }^{1}$ Elderly patients with femoral neck fractures are particularly at risk, and as many as $60 \%$ may develop sores, most of which occur within the first five days of admission to hospital. ${ }^{2}$ Many such patients spend unacceptably long periods on high pressure surfaces, particularly in casualty and in the operating theatre, and many go on to develop sores, though the relation may not be causal. ${ }^{3}$ It is possible that acute illness may be more important by exacerbating liability to pressure necrosis because of reduced feeling and mobility, pain, low blood pressure, and nutritional deficiency. Other factors, such as confusion and incontinence, may also be important. ${ }^{45}$

The benefits of supplementary nutritional support in patients with femoral neck fracture have been reported ${ }^{67}$ and there is evidence that undernutrition may be a predisposing factor in pressure sore development. ${ }^{8}$ However, the contribution of pre-existing specific nutritional deficiencies to the risk of pressure sore development has not been studied.

Zinc is an essential element which has a crucial role in immunity and healing and for which interactions with other vitamins have been described. ${ }^{9}$ Both topical and oral zinc supplementation have a beneficial effect on wound healing in zinc depleted subjects. ${ }^{10}$ Vitamin $\mathrm{C}$ has also been shown to promote wound healing and may have a role in immunological regulation. ${ }^{9}$ Elderly people are particularly at risk from both nutritional deficiencies and depressed immunity, and studies in this hospital have shown a high prevalence of zinc ${ }^{11}$ and vitamin ${ }^{12}$ depletion in elderly inpatients.

This study was undertaken to assess the contribution of nutritional status to the development of pressure sores in elderly patients with femoral neck fractures.

\section{Subjects and methods}

Twenty one unselected patients aged 75 or more admitted to the orthopaedic unit with a diagnosis of femoral neck fracture were invited to participate in the study, which was approved by the local clinical research (ethics) committee. Written informed consent was obtained from all patients or their next of kin. Pressure sores were defined as a full thickness epidermal break over a pressure bearing surface.

A preoperative fasting blood sample was obtained at 8-9 am on the day after admission for assay of various biochemical nutritional indices, including plasma and polymorphonuclear leucocyte zinc; plasma albumin 
and vitamin $\mathrm{A}$ and $\mathrm{E}$; leucocyte total vitamin $\mathrm{C}$; and haemoglobin concentrations. All samples were processed within 30 minutes of venepuncture. Permission was also sought to take a muscle biopsy sample during pinning and plating of the fracture for zinc analysis. ${ }^{13}$ Plasma and polymorphonuclear leucocyte zinc concentrations were measured as described. ${ }^{14}$ Vitamin $\mathrm{A}$ and $\mathrm{E}$ concentrations were measured by high performance liquid chromatography, ${ }^{15}$ and leucocyte vitamin $\mathrm{C}$ was measured spectrophotometrically by means of a well established technique. ${ }^{16}$ Albumin and haemoglobin concentrations were measured by standard methods.

Patients were subsequently grouped into those who developed pressure sores and those who did not, and results were compared with findings in a group of 12 well elderly people who were free living in the community. The zinc status of these subjects has been described. ${ }^{13}$ Results are expressed as means and standard deviation (SD). Differences between groups were compared by using Student's $t$ test and taken as significant when $\mathrm{p}<0 \cdot 05$.
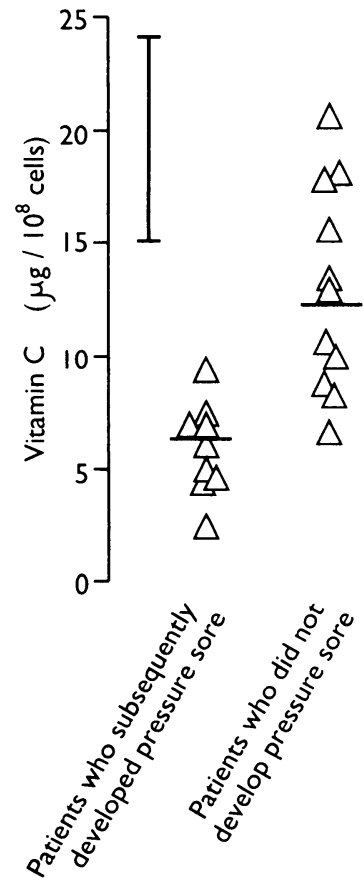

Leucocyte vitamin $C$ concentrations in elderly patients with femoral neck fractures. V'erticai bar is adult reference range. Horizontal bars are means $\mathrm{p}<0.001)$. All the patients who had sores and eight of

\section{Results}

Ten of the 21 patients (48\%) subsequently developed pressure sores (table). Indices of zinc status, plasma vitamin $\mathrm{A}$ and $\mathrm{E}$ concentrations, and albumin and haemoglobin concentrations did not differ appreciably between patients who developed pressure sores and those who did not (table).

Plasma zinc values were lowest in patients who did not develop sores, associated with reduced plasma albumin concentrations (table). The polymorphonuclear leucocyte zinc concentration was similar to that in the healthy elderly controls ${ }^{13}$ both in patients with and in those without sores. A significant correlation was found between polymorphonuclear leucocyte and muscle zinc values $(r=0.78 ; \mathrm{p}<0.01)$. Values were similar to those obtained from the rectus abdominis in a study of elderly surgical patients. ${ }^{13}$

Vitamin E concentrations in the patients studied were similar to those in well elderly subjects, but vitamin A concentrations were lower in both patient groups than in the healthy elderly group (table).

Leucocyte total vitamin $\mathrm{C}$ concentration was significantly lower in the patients who developed pressure sores than in those who did not $(6 \cdot 3$ (SD 2.2) $\mu \mathrm{g} / 10^{8}$ cells as compared with $12 \cdot 8(4 \cdot 6) \mu \mathrm{g} / 10^{8}$ cells; those who did not had values below this laboratory's winter reference range $\left(<15 \mu \mathrm{g} / 10^{8} \text { leucocytes }\right)^{17}$ (figure).

\section{Discussion}

Using polymorphonuclear leucocyte and muscle zinc values, which are thought to provide a good index of zinc status, we found no evidence of zinc depletion in our patients and conclude that this was not a contributory factor to pressure sore development.

However, vitamin $\mathrm{C}$ depletion was associated with pressure sores in this study. This finding agrees with a report of a higher incidence of pressure lesions in elderly women with femoral neck fractures who had vitamin $C$ intakes of less than the dietary reference value for this age group $(40 \mathrm{mg} /$ day $) .^{18}$

Leucocyte vitamin C concentrations show an apparent decrease when numbers of neutrophils increase after surgery or infection, since these cells contain only one third of the vitamin $\mathrm{C}$ of mononucleat leucocytes. ${ }^{19}$ However, in this study patients wer investigated preoperatively, immediately after admission, and both total and differential leucocyt counts were normal in both groups. In this settin leucocyte vitamin $\mathrm{C}$ value is a good index.of vitamin reserves. ${ }^{919}$ It is therefore reasonable to assume that i some of our patients there was a pre-existing vitamin $\varnothing$ deficit which apparently influenced the subsequent development of a pressure lesion.

Vitamin C has been implicated in collagen formatio $\vec{D}$ via hydroxylation of proline and thus influences wound healing. It is a powerful antioxidant with ant inflammatory potential by neutralisation of phagocyte derived oxidants. Supplementation with vitamin $f$. increases lymphocyte proliferative responses, neutros phil migration, and neutrophil-macrophage infiltra tion to sites of infection. ${ }^{9}$ Hence a vitamin $\mathrm{C}$ defica would probably have an adverse effect on tissu@ recovery after a period of ischaemia. Indeed, a singl\& report in 1974 showed improved healing of existing pressure sores in patients given supplements of vitamion C. ${ }^{20}$

Although development of pressure sores in patients with femoral neck fractures has been well studied there is still no clear cut risk factor which determineg why one patient should develop a sore given the same conditions as another patient. In summary we have shown that vitamin $\mathrm{C}$ but not zinc, vitamin $\mathrm{A}$, ộ vitamin $\mathrm{E}$ depletion was associated with subsequent development of pressure sores in elderly subjects wit femoral neck fractures.

We are grateful to the orthopaedic consultants at St James University Hospital for allowing us to study their patients? and to Mrs E Tasker for secretarial assistance.

1 Allman RM. Epidemiology of pressure sores in different population 3 Decubitus 1989;2:30-3.

2 Versluysen $M$. How elderly patients with femoral fracture develop pressuri sores. $B M \mathcal{H}$ 1986;292:1311-3.

3 Hughes AW. Prevention of pressure sores in patients with fractures of the femoral neck. Injury 1986;17:19-22.

4 Preventing pressure sores. Lancet 1990;335:1311-2.

5 Barrett E. A review of risk assessment methods. Care, Science, Practiv 1988;6:49-52.

6 Bastow MD, Rawlings J, Allison SP. Benefits of supplementary tube feedirio after fractured neck of femur: a randomised controlled trial. $B M$ 1983;287:1589-92.

7 Delmi M, Rapin C-H, Bengoa J-M, Delmas PD, Vasey H, Bonjour J Dietary supplementation in elderly patients with fractured neck of femuro
Lancet 1990;335:1013-6.

8 Breslow R. Nutritional status and dietary intake of patients with pressurs ulcers: review of research literature 1943-1989. Decubitus 1991;4:16-21.

Machlin LJ, ed. Handbook of vitamins, nutritional, biochemical and clinich aspects. New York: Marcel Dekker, 1984

10 Agren MS. Studies on zinc in wound healing. Linkoping, Sweden: Linkopin Universtudies on zinc in wound healing. Link

11 Goode HF, Pen ND, Kelleher J, Walker BE. Evidence of depletion in hospitalised but not healthy elderly subjects. Age Agein 1991:20:345-8.

1991;20:345-8.
12 Penn ND, Purkins L, Kelleher K, Heatley RV, Mascie-Taylor BH, Belfief $\mathrm{PW}$. The effect of dietary supplementation with vitamins $A, C$ and $E$ on cof

\begin{tabular}{|c|c|c|c|c|c|c|c|c|c|c|}
\hline & No & Sex & $\begin{array}{c}\text { Age range } \\
\text { (years) }\end{array}$ & $\begin{array}{c}\text { Plasma zinc } \\
(\mu \mathrm{mol} / \mathrm{l})\end{array}$ & $\begin{array}{l}\text { Polymorpho- } \\
\text { nuclear } \\
\text { leucocyte zinc } \\
\text { (nmol/mg } \\
\text { protein) }\end{array}$ & $\begin{array}{c}\text { Muscle } \\
\text { zinc } \\
\text { (nmol/mg } \\
\text { protein) }\end{array}$ & $\underset{(\mu \mathrm{g} / \mathrm{dl})}{\operatorname{Vitamin}} \mathrm{A}$ & $\underset{(\mathrm{mg} / \mathrm{dl})}{\text { Vitamin }} \mathrm{E}$ & $\underset{(\mathrm{g} / \mathrm{dl})}{\text { Albumin }}$ & $\underset{(\mathrm{g} / \mathrm{l})}{\operatorname{Cog}}$ \\
\hline Patients who developed pressure sore & 10 & $\begin{array}{l}8 \mathrm{~F} \\
2 \mathrm{M}\end{array}$ & $76-96$ & $9 \cdot 4(2 \cdot 6)$ & $1 \cdot 02(0 \cdot 13)$ & $4 \cdot 7(0 \cdot 6)$ & $38.3(9 \cdot 5)^{\star}$ & $10 \cdot 4(2 \cdot 5)$ & $33 \cdot 1(3 \cdot 8)^{\star}$ & $116(18) \stackrel{\text { ఫ్ }}{\overline{\bar{n}}}$ \\
\hline Patients who did not develop pressure sore & 11 & $\begin{array}{l}8 \mathrm{~F} \\
3 \mathrm{M}\end{array}$ & $76-88$ & $8 \cdot 1(1 \cdot 6)^{\star}$ & $1 \cdot 02(0 \cdot 28)$ & $4 \cdot 5(0 \cdot 6)$ & $42 \cdot 9(17 \cdot 2) \dagger$ & $9 \cdot 6(4 \cdot 8)$ & $35 \cdot 5(4 \cdot 8)^{\star}$ & 125 (19) \\
\hline Well eiderly & 12 & $\begin{array}{l}6 \mathrm{~F} \\
6 \mathrm{M}\end{array}$ & $75-86$ & $10 \cdot 8(1 \cdot 1)$ & $1 \cdot 11(0 \cdot 20)$ & - & $62 \cdot 5(16 \cdot 5)$ & $10 \cdot 4(2 \cdot 3)$ & $43 \cdot 9(2 \cdot 6)$ & - \\
\hline
\end{tabular}

$\star$ Significantly lower than well elderly group $(p<0 \cdot 001) . \quad+$ Significantly lower than well elderly group $(p<0 \cdot 02)$. 
mediated immune function in elderly long-stay patients: a randomised controlled trial. Age Ageing 1991;20:169-74.

13 Goode HF, Kelleher J, Walker BE, Hall RI, Guillou PJ. Cellular and muscle zinc in surgical patients with and without gastrointestinal cancer. Clin $\mathrm{Sc}$ 1990;79:247-52.

14 Goode HF, Kelleher J, Walker BE. Zinc concentrations in pure populations of peripheral blood neutrophils, lymphocytes and monocytes. Ann Clin Biochem 1989;26:89-95.

15 Catignami GL, Bieri JG. Simultaneous determination of retinol and (2tocopherol in serum or plasma by liquid chromatography. Clin Chem 1983;29:708-12.

16 Denson KW, Bowers EF. The determination of ascorbic acid in white blood cells. Clin Sci 1961;21:157-62.
17 Morgan AG, Kelleher J, Walker BE, Losowsky MS, Droller H, Middleton RSW. A nutritional survey in the elderly: blood and urine vitamin levels. Int $\mathcal{F}$ Vitam Nutr Res 1975;45:448-62.

18 Brown KM, Seabrook NA. Nutritional influences on recovery and length of hospital stay in elderly women following femoral fracture [abstract]. Proc Nutr Soc (in press)

19 Schorah CJ, Habibzadeh N, Hancock M, King RFGJ. Changes in plasma and buffy layer vitamin $C$ concentrations following major surgery: what do they reflect? Ann Clin Biochem 1986;23:566-70.

20 Taylor TV, Rimmer S, Day B, Butcher J, Dymock IW Ascorbic acid supplementation in the treatment of pressure sores. Lancet 1974;ii:544-6.

(Accepted 1 September 1992

\title{
Comparison of Yuzpe regimen, danazol, and mifepristone (RU486) in oral postcoital contraception
}

\author{
Anne M C Webb, Jean Russell, Max Elstein
}

\begin{abstract}
Objective-To compare the effectiveness and acceptability of three regimens of postcoital contraception.

Design-Randomised group comparison of ethinyloestradiol $100 \mu \mathrm{g}$ plus levonorgestrel $500 \mu \mathrm{g}$ repeated after 12 hours (Yuzpe method); danazol 600 $\mathrm{mg}$ repeated after 12 hours; and mifepristone $600 \mathrm{mg}$ single dose.
\end{abstract}

Setting-Community family planning clinic.

Subjects-616 consecutive women with regular cycles aged 16 to 45 years.

Main outcome measures-Number of pregnancies, incidence of side effects, and timing of next period.

Results-The raw pregnancy rates (with 95\% confidence intervals) for the Yuzpe, danazol, and mifepristone groups were $2.62 \%(0.86 \%$ to $6.00 \%)$, $4 \cdot 66 \%(2 \cdot 15 \%$ to $8 \cdot 67 \%)$, and $0 \%(0 \%$ to $1 \cdot 87 \%)$ respectively. Overall, these rates differed significantly $\left(\chi^{2}=8.988, \mathrm{df}=2 ; \mathrm{p}=0.011\right)$. The differences between the mifepristone and Yuzpe groups and between the mifepristone and danazol groups were also significant. Side effects were more common and more severe in the Yuzpe group (133 women (70\%)) than in either the danazol group $(58(30 \%))$ or the mifepristone group ( $72(37 \%))$. The Yuzpe regimen tended to induce bleeding early but mifepristone prolonged the cycle. Three women bled more than seven days late in the Yuzpe group compared with 49 in the mifepristone group.

Conclusions-Mifepristone was effective in University of Manchester, Department of Obstetrics and Gynaecology, Palatine Centre, Manchester M20 9LJ

Anne M C Webb, clinical research fellow

\section{Department of Medical} Statistics, University

Hospital of South Manchester, Manchester M20 8LR

Jean Russell, medical statistician

Department of Obstetrics and Gynaecology, University Hospital of South Manchester, Manchester M20 8LR Max Elstein, professor

Correspondence and requests for reprints to: Dr Webb.

$B M \mathcal{1 9 9 2 ; 3 0 5 : 9 2 7 - 3 1}$ regimen was preferable because of the shorter dura of treatment. ${ }^{5}$ Estimating the numbers of expected pregnancies is difficult but a reduced incidence has been shown when compared with numbers predicted by various methods. ${ }^{26.9}$ The Yuzpe regimen has become an accepted and recommended method of postcoital contraception..$^{10}$

Danazol has been suggested to be as effective as the Yuzpe method with fewer side effects."112 The antiprogesterone drug mifepristone has been shown to be an effective abortifacient and has been used as an interceptive and menstrual regulator, ${ }^{13.15}$ although it causes considerable cycle upset. ${ }^{1617}$ We conducted a study to compare the effectiveness and side effects of these three methods (Yuzpe, danazol, mifepristone).

\section{Subjects and methods}

Women requesting emergency contraception after only one act of unprotected intercourse during their current cycle were considered for study if they presented within 72 hours of the act. Only women with regular cycles were included. The length of the cycle could vary from 21 to 35 days, but for one individual the variation over the previous three months could not exceed four days. Women who had been pregnant in the previous three months were excluded. The study was restricted to women who were aged 16-45 years, willing to sign consent, and available for follow up. Women with contraindications to oestrogen or progestogen (thromboembolic disease, liver disease, breast cancer, diabetes, jaundice, or pruritus of pregnancy), with known or suspected adrenal disease, or who were taking interacting drugs (liver enzyme inducers, broad spectrum antibiotics) were excluded. No woman had taken any sex steroids since her last menstruation. All women were interviewed by the same person $(A M C W)$

The date of the last menstruation, cycle length, and exact time of unprotected intercourse were noted. Any use of contraception (coitus interruptus, failed barrier), height, weight, and previous pregnancies and their outcome were recorded. Serum progesterone concentration was measured by quantitative radioimmunoassay.

Subjects were randomly allocated to receive the Yuzpe regimen (ethinyloestradiol $100 \mu \mathrm{g}$ and levonorgestrel $500 \mu \mathrm{g}$ repeated after 12 hours), danazol 600 $\mathrm{mg}$ repeated after 12 hours, or mifepristone $600 \mathrm{mg}$ one dose only. The allocation schedule was constructed by using a computer based pseudorandom number generator with a uniform distribution. The schedule was prepared before the start of the study by JR, who did not participate in either the selection or assessment of women. The mifepristone was always taken in the clinic. The other two drug regimens were also always started within 72 hours of unprotected intercourse but the first dose was often taken after the visit to the clinic to obviate taking the tablets on an empty stomach or 